\title{
Orexins Protect Neuronal Cell Cultures Against Hypoxic Stress: an Involvement of Akt Signaling
}

\author{
Paulina Sokołowska • Anna Urbańska • Kaja Biegańska • \\ Waldemar Wagner • Wojciech Ciszewski • \\ Magdalena Namiecińska • Jolanta B. Zawilska
}

Received: 30 September 2013 / Accepted: 24 October 2013/Published online: 19 November 2013

(C) The Author(s) 2013. This article is published with open access at Springerlink.com

\begin{abstract}
Orexins A and B are peptides produced mainly by hypothalamic neurons that project to numerous brain structures. We have previously demonstrated that rat cortical neurons express both types of orexin receptors, and their activation by orexins initiates different intracellular signals. The present study aimed to determine the effect of orexins on the Akt kinase activation in the rat neuronal cultures and the significance of that response in neurons subjected to hypoxic stress. We report the first evidence that orexins A and B stimulated Akt in cortical neurons in a concentrationand time-dependent manner. Orexin B more potently than orexin A increased Akt phosphorylation, but the maximal effect of both peptides on the kinase activation was very similar. Next, cultured cortical neurons were challenged with cobalt chloride, an inducer of reactive oxygen species and hypoxia-mediated signaling pathways. Under conditions of chemical hypoxia, orexins potently increased neuronal viability and protected cortical neurons against oxidative stress. Our results also indicate that Akt kinase plays an important role in the prosurvival effects of orexins in neurons, which implies a possible mechanism of the orexin-induced neuroprotection.
\end{abstract}

Keywords Orexin $\cdot$ Akt kinase $\cdot$ Neuroprotection $\cdot$ Chemical hypoxia

P. Sokołowska $\cdot$ A. Urbańska $\cdot$ K. Biegańska $\cdot$ W. Wagner $\cdot$

W. Ciszewski $\cdot$ M. Namiecińska $\cdot$ J. B. Zawilska $(\triangle)$

Institute of Medical Biology, Polish Academy of Sciences,

Lodowa 106, 93-232 Łódź, Poland

e-mail: jolanta.zawilska@umed.lodz.pl

K. Biegańska • J. B. Zawilska

Department of Pharmacodynamics, Medical University of Łódź,

Muszynskiego 1, 90-151 Łódź, Poland

\author{
Abbrevations \\ MAPK Mitogen-activated protein kinase \\ $\mathrm{OX}_{1} \mathrm{R}$ Type 1 orexin receptor \\ $\mathrm{OX}_{2} \mathrm{R} \quad$ Type 2 orexin receptor \\ PA Phosphatidic acid \\ PLC Phospholipase C
}

\section{Introduction}

Orexins are neuropeptides discovered simultaneously in 1998 by two independent research groups, one of which named them orexins (A and B) and the other hypocretins (hypocretin-1 and hypocretin-2) (de Lecea et al. 1998; Sakurai et al. 1998). Orexins A (33 amino acids) and B (28 amino acids) are proteolytically processed from a common precursor peptide, preproorexin (Alvarez and Sutcliffe 2002). Both neuropeptides interact with $\mathrm{G}$ protein-coupled receptors, types $1\left(\mathrm{OX}_{1} \mathrm{R}\right)$ and 2 orexin receptor $\left(\mathrm{OX}_{2} \mathrm{R}\right)$, which display different affinity for orexins (Voisin et al. 2003). On the basis of binding and $\mathrm{Ca}^{2+}$ elevation studies in recombinant expression systems, it has been established that orexin A couples to $\mathrm{OX}_{1} \mathrm{R}$ with a 5- to 100-fold higher affinity than orexin $\mathrm{B}$, whereas both peptides have similar affinities to $\mathrm{OX}_{2} \mathrm{R}$ (Ammoun et al. 2003; Sakurai et al. 1998). OXRs are widely distributed in the central nervous system and peripheral tissues. Interestingly, orexin-containing neuronal cell bodies, although localized only in lateral hypothalamic area and nearby regions, project to numerous brain structures and are regulated by many neurotransmitter systems (Kukkonen et al. 2002; Kukkonen 2012; Nambu et al. 1999; Peyron et al. 1998). This anatomical architecture of orexin neurons and the wide distribution of orexin receptors appear to be essential for multiple functions of these neuropeptides. Orexins were originally described to play a key role in the control of feeding 
and sleep-wake cycle, with an emphasis on their contribution to the pathogenesis of narcolepsy, but since their discovery many other physiological functions of the peptides have been well-documented, i.e., regulation of motivated behaviors, such as arousal, reward-seeking and drug addiction, metabolic rate and thermogenesis, autonomic or endocrine processes (Aston-Jones et al. 2010; Berthoud et al. 2005; Chemelli et al. 1999; Mieda et al. 2004; Randeva et al. 2001; Sakurai et al. 1998; Spinazzi et al. 2006; Thompson and Borgland 2011; Zhang et al. 2009). Multitude of physiological actions controlled by orexins originates from highly diverse cellular responses to the orexin receptors stimulation. It has been demonstrated that stimulation of orexin receptors may trigger activation of classical phospholipase C (PLC) cascade (PLC$\mathrm{IP}_{3} / \mathrm{DAG}$ ) with a subsequent robust increase in intracellular $\mathrm{Ca}^{2+}$ concentration in recombinant cell lines and native systems (Johansson et al. 2007; Lund et al. 2000; Mazzocchi et al. 2001; Randeva et al. 2001). Other orexin-activated signaling pathways include adenylyl cyclase (AC)/cyclic AMP, phospholipase $\mathrm{D} /$ phosphatidic acid (PA), phospholipase $\mathrm{A}_{2}$ /arachidonic acid release and mitogen-activated protein kinase (MAPK)/stress-activated protein kinase (Holmqvist et al. 2005; Magga et al. 2006; Tang et al. 2008; Urbańska et al. 2012; Woldan-Tambor et al. 2011; Zhu et al. 2003). Despite a large number of orexins-mediated signaling pathways described in the literature, a role of these neuropeptides in activation of Akt kinase is at present largely unknown. Therefore, the aim of our work was to study the effect of orexins on the Akt kinase activation in primary neuronal cell cultures.

It has been demonstrated that, depending on the activated signal cascade, orexins can affect different cellular processes, such as neuronal excitation, cell growth, plasticity, death or survival (Ammoun et al. 2006; Holmqvist et al. 2005; Kukkonen 2012; Ramanjaneya et al. 2009; Rouet-Benzineb et al. 2004; Tang et al. 2008). Recent studies in a model of cerebral ischemia in rats indicated a new role of orexin A as a neuroprotective factor. The peptide was shown to attenuate ischemia-reperfusion injury by reducing the number of apoptotic cells (Kitamura et al. 2010; Yuan et al. 2011). As ischemia is a restriction in blood supply to the tissue, causing a shortage of oxygen and glucose needed for cellular metabolism, in the present study we also tested neuroprotective potential of both orexins in neuronal cultures derived from rat cerebral cortex subjected to hypoxic stress induced by cobalt chloride. Cobaltous ions mimic hypoxia conditions by activation of hypoxia-mediated signaling pathways and generation of reactive oxygen species (ROS) (Chandel et al. 1998; Vengellur and LaPres 2004). Finally, as Akt kinase is well known for its ability to control cellular survival and apoptosis, we checked whether this kinase is involved in neuroprotective effects of orexins in cells subjected to chemical hypoxia.

\section{Materials and Methods}

\section{Animals and Neuronal Cell Culture}

Experiments were performed on primary neuronal cell cultures prepared from Wistar rat embryos on day 17 of gestation. Animal procedures were in a strict accordance with the Polish governmental regulations concerning experiments on animals (Dz.U.05.33.289), and the experimental protocol was approved by the Local Ethical Commission for Experimentation on Animals.

Primary neuronal cell cultures were prepared according to the method of Brewer (1995), as previously described in detail (Nowak et al. 2007; Urbańska et al. 2012). Briefly, the rat cerebral cortex was isolated from fetal brain, incubated for $15 \mathrm{~min}$ in trypsin/EDTA $(0.05 \%)$ at $37{ }^{\circ} \mathrm{C}$ followed with a trituration in a solution of DNase I $(0.05 \mathrm{mg} / \mathrm{ml})$ and fetal bovine serum $(20 \%)$ in $\mathrm{Ca}^{2+}$ - and $\mathrm{Mg}^{2+}$-free PBS. The cells were maintained in Neurobasal medium supplemented with B27 (2\%), $2 \mathrm{mM}$ glutamine, $100 \mathrm{U} / \mathrm{ml}$ penicillin, and $100 \mu \mathrm{g} /$ $\mathrm{ml}$ streptomycin. Seventy-two hours after plating, the cellular proliferation was stopped by adding to the medium the solution of $1-\beta$-D-arabinofuranosylcytosine $(5 \mu \mathrm{M})$. The glial content in neuronal cultures, analyzed by using antibody against glial fibrillary acidic protein, was estimated to be 6$10 \%$ of the total cell population (Urbańska et al. 2012). Cells were cultured as monolayer on poly-L-ornithine coated multi-well plates or $60 \mathrm{~mm}$ culture dishes for 7-8 days before experiments at $37{ }^{\circ} \mathrm{C}$ in a humidified atmosphere with $5 \% \mathrm{CO}_{2}$.

\section{Protein Extraction and Western Blot Analysis}

Whole cell extracts were prepared from neuronal cultures treated with orexins to activate Akt. Briefly, following treatments cells were washed in ice-cold PBS and removed from the surface by scraping in cell lysis buffer (M-PER Mammalian Protein Extraction Reagent, Thermo Scientific, Rockford, IL, USA) with protease and phosphatase inhibitors (Halt Protease and Phosphatase Inhibitor Cocktail, Thermo Scientific, Rockford, IL, USA) according to the manufacturer's instructions. Cell extracts were collected and stored at $-70{ }^{\circ} \mathrm{C}$ until protein concentration was measured by the Pierce BCA Protein Assay Kit (Thermo Scientific, Rockford, IL, USA). Electrophoresis and blotting was performed using NuPAge Novex system with the XCell SureLock Mini-Cell and the Novex Semi-Dry Blotter (Invitrogen, Paisley, UK) according to the manufacturer's instruction. Denatured samples with an equal amount of protein per lane $(20 \mu \mathrm{g})$ were separated on gradient gels (4-12\% Bis-Tris gel), electrotransferred on nitrocellulose membrane (Hybond C extra, Amersham Biosciences, Buckinghamshire, UK) and blocked in $5 \%(w / v)$ bovine serum albumin in TBST $(0.1 \%$ Tween-20 in Tris Buffered Saline, 
TBS), for $1 \mathrm{~h}$ at room temperature. After $4{ }^{\circ} \mathrm{C}$ overnight incubation with primary antibodies (phospho ${ }^{\mathrm{Ser} 473}$-Akt, 1:1, 000, Cell Signaling Technology, Danvers, MA, USA) membranes were washed several times in TBST, and then incubated in TBST-milk with horse radish peroxidase-conjugated secondary antibodies (anti-rabbit $\operatorname{IgG}, 1: 2,000$, Dako, Glostrup, Denmark) for $1 \mathrm{~h}$ at room temperature. Peroxidase enzymatic activity was detected using Super Signal West Pico Chemiluminescent Substrate (Thermo Scientific, Rockford, IL, USA) and visualized on G-box iChemi XT4 system utilizing GeneSys automatic control software (Syngene, Cambridge, UK). Then, membranes were stripped in Restore Western Blot Stripping Buffer (Thermo Scientific, Rockford, IL, USA) for $10 \mathrm{~min}$ at room temperature and after extensive washing reprobed with total Akt antibody (1:1,000, Cell Signaling Technology, Danvers, MA, USA). The same secondary antibody and detection system was used as described above. The phospho-specific signal was correlated to the total Akt.

\section{Cell Viability Assay}

Cell viability and mitochondrial function were measured by 3-(4,5-dimethyl-2-thiazolyl)-2,5-diphenyl-2 $H$-tetrazolium bromide (MTT) reduction to MTT formazan by cellular mitochondrial dehydrogenases. Following exposure to orexin A, orexin $\mathrm{B}$, and cobalt chloride, neuronal cells were washed in PBS before the addition of MTT $(0.5 \mathrm{mg} / \mathrm{ml})$ and incubated for $3 \mathrm{~h}$ at $37{ }^{\circ} \mathrm{C}$. Formazan crystals were solubilized in dimethyl sulfoxide $(100 \%)$ and absorbance, proportional to the number of viable cells, was measured at $570 \mathrm{~nm}$ using a microplate reader (EnVision 2103, Perkin Elmer, Turku, Finland).

\section{Reduced-MitoTracker Orange Staining}

We monitored oxidative stress in rat neuronal cultures by utilizing a dye that is internalized within cells and does not fluoresce until its reduced moieties are oxidized. MitoTracker Orange CM$\mathrm{H}_{2}$ TMRos (Invitrogen, Paisley, UK) was successfully used to study ROS generation in neurons (Ibarretxe et al. 2006; Kweon et al. 2001; Lampe et al. 2010). After 24-h incubation of rat neuronal cultures with orexins $\mathrm{A}$ and $\mathrm{B}$ in the presence or absence of cobalt chloride $(100 \mu \mathrm{M})$, culture medium was removed and the cells were stained with $\mathrm{CM}-\mathrm{H}_{2}$ TMRos according to the manufacturer's instruction. Finally, the cells were washed with PBS, counterstained with $2 \mu \mathrm{g} / \mathrm{ml}$ Hoechst 33342 for $20 \mathrm{~min}$, and subjected for analysis by high content reader ArrayScan VTI HCS Reader (Thermo Scientific, Rockford, IL, USA) equipped with $\times 10$ objective. Routinely, images of 20 fields/well were acquired and 5000 cells/well were analyzed with Cell Health Profiling Bioapplication V3 software (Cellomics BioApplications, Cellomics, Thermo Scientific, Rockford, IL, USA). Oxidative stress level in rat cortical neurons was calculated on the basis of mean cellular fluorescence and expressed as a percentage of the respective control.

\section{Chemicals}

Orexins A and B were from NeoMPS (Strasbourg, France). Poly- $L$-ornithine, DNase I, trypsin, glutamine, penicillin, streptomycin, 1- $\beta$-D-arabinofuranosylcytosine, 3-(4,5-dimethyl-2-thiazolyl)-2,5-diphenyl-2 $H$-tetrazolium bromide (MTT), dimethyl sulfoxide, cobalt chloride, TBS, Tween 20, albumin from bovine serum, non-fat dried bovine milk were from Sigma-Aldrich (Poznan, Poland). 10-DEBC (10-[4'-( $N$, $N$-diethylamino)butyl]-2-chlorophenoxazine hydrochloride) and GSK690693 (4-[2-(4-amino-1,2,5-oxadiazol-3-yl)-1-ethyl-7-[(3S)-3-piperidinylmethoxy)-1 $H$-imidazo[4,5-c]pyridin4-yl]-2-methyl-3-butyn-2-ol) were from Tocris Bioscience (Bristol, UK). Neurobasal medium, B27, fetal bovine serum, CM- $\mathrm{H}_{2}$ TMRos, NuPAGE MES SDS Running Buffer, NuPAGE Transfer Buffer were from Invitrogen (Paisley, UK).

\section{Data Analysis}

Data are expressed as mean \pm standard error of the mean (SEM) values and were analyzed for statistical significance by one-way ANOVA followed by post hoc StudentNewman-Keul's test, using GraphPad Prism 5 (GraphPad, San Diego, CA, USA).

\section{Results}

Orexins Stimulate the Akt kinase Activity in Rat Cortical Neurons

Orexins A and B evoked phosphorylation of Akt kinase in cultured rat cortical neurons. The kinetics of Akt activation by orexins was analyzed by Western blot, using an antibody that detects endogenous levels of Akt when phosphorylated (activated) at $\mathrm{Ser}^{473}$. Under resting conditions the activity of Akt in neuronal cells was very low, but upon stimulation of the cells with $0.1 \mu \mathrm{M}$ orexins A and B it increased significantly (Fig. 1, top). The maximal phosphorylation of Akt (approximately $500 \%$ above the control values) was observed after $1 \mathrm{~h}$ of stimulation by orexins and decreased toward a plateau between 6-24 h. After $24 \mathrm{~h}$ stimulation of cortical neurons with orexins, the phospho-Akt immunoreactivity still remained higher than the basal level (114 and $76 \%$ above control for orexins A and B, respectively) (Fig. 1, bottom). The profile of action of both peptides was very similar (Fig. 1, bottom).

A dose-dependence study showed that orexins, incubated with neuronal cells for $1 \mathrm{~h}$, were able to activate Akt kinase at all concentrations tested (0.0001-1 $\mu \mathrm{M})$ (Fig. 2). Interestingly, 
Fig. 1 Effects of orexins A and $\mathrm{B}$ on the Akt activation in primary neuronal cultures from rat cerebral cortex. Cells were incubated with the peptides $(0.1 \mu \mathrm{M})$ for the indicated time periods and analyzed by immunoblot against pAkt $\left(\mathrm{Ser}^{473}\right)$. Top panel shows results of representative experiments. Data are presented as mean $\pm \mathrm{SEM}$ of 4-7 values per group and expressed as a percentage of the respective control. Asterisks indicate statistically significant difference from control; $* P<0.05 ; * * * P<0.001$

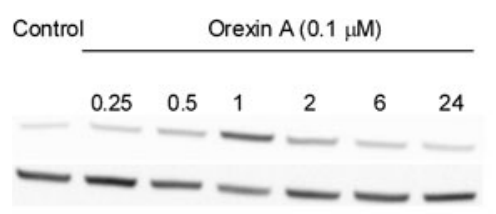

Control Orexin B $(0.1 \mu \mathrm{M})$
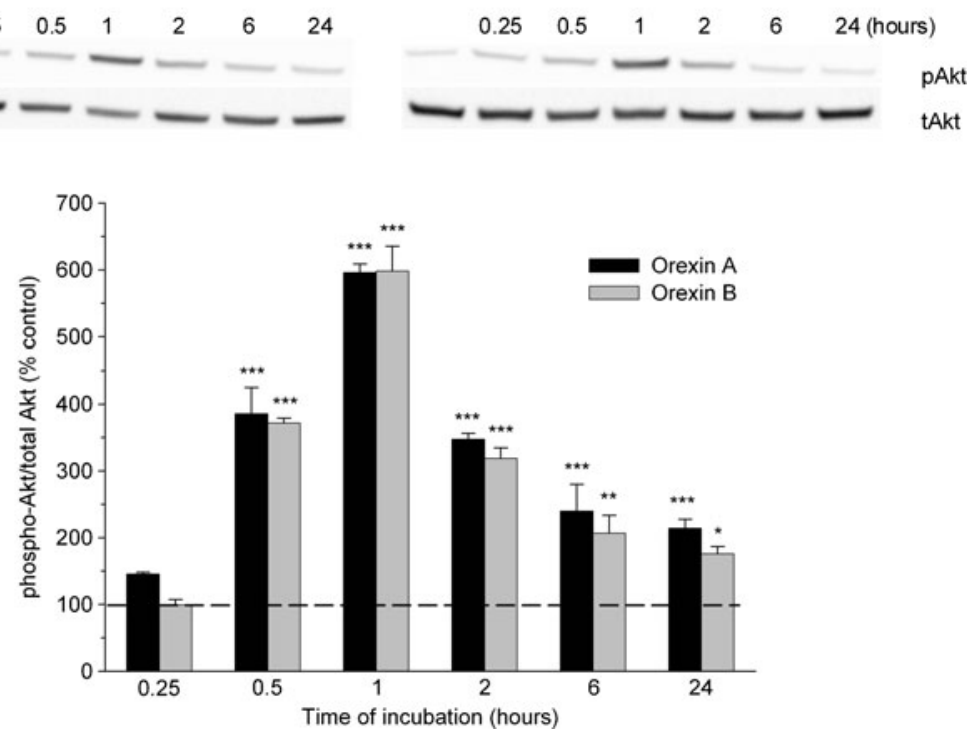

orexin $\mathrm{B}$ more potently $\left(\mathrm{EC}_{50}=1.8 \mathrm{nM}\right)$ than orexin $\mathrm{A}\left(\mathrm{EC}_{50}=7\right.$ $\mathrm{nM}$ ) stimulated Akt phosphorylation but, as described above, the maximal effect of both peptides on the Akt activation was very similar (Fig. 2, bottom).

Orexins Protect Neurons from the Cobalt Chloride-Induced Toxicity

Cultured cortical neurons were challenged with $100 \mu \mathrm{M}$ cobalt chloride and cell viability and mitochondrial function were measured by MTT test. Incubation of cortical neurons with cobalt chloride for $48 \mathrm{~h}$ resulted in a potent, about $50 \%$, reduction of cell viability as compared with control values (taken as $100 \%$ ). Parallel incubation of neurons with orexins $(0.0001-1 \mu \mathrm{M})$ attenuated the toxic effect of cobalt chloride (Fig. 3). Under conditions of chemical hypoxia, orexin A induced a statistically significant (at $0.01-1 \mu \mathrm{M}$ concentration range) increase of neuronal cell viability, with the highest response, up to $71 \%$ of control values, observed at $0.1 \mu \mathrm{M}$ (Fig. 3, top). Orexin B more potently than orexin A enhanced cell viability by $80 \%$ of control values at $0.01 \mu \mathrm{M}$ and protected neurons at a wider range of concentrations (0.0001-1 $\mu \mathrm{M})$ (Fig. 3, bottom).
Fig. 2 Concentration-dependent effects of orexins A and B on the Akt activation in primary rat neuronal cultures. Cells were incubated with the peptides $(0.0001-1 \mu \mathrm{M})$ for $1 \mathrm{~h}$ and analyzed by immunoblot against pAkt $\left(\mathrm{Ser}^{473}\right)$. Top, results of representative experiments. Data are presented as mean \pm SEM of 4-7 values per group and expressed as a percentage of the respective control. Asterisks indicate statistically significant difference from control; $* P<0.05 ; * * * P<0.001$

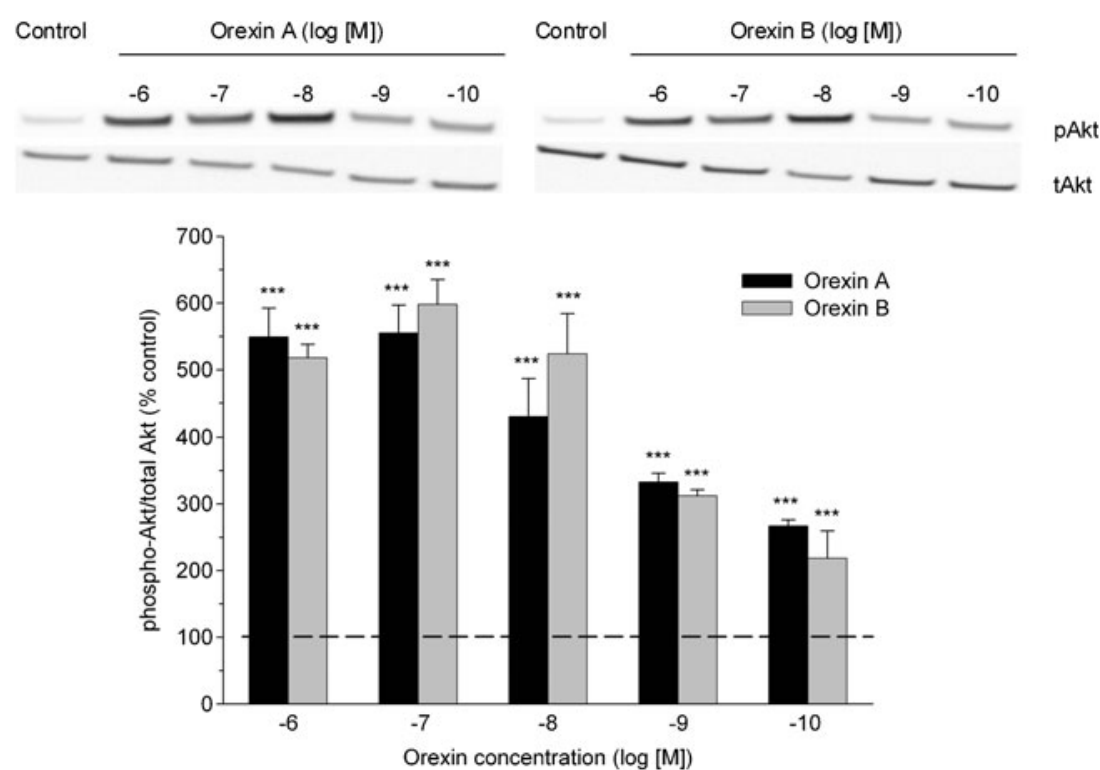



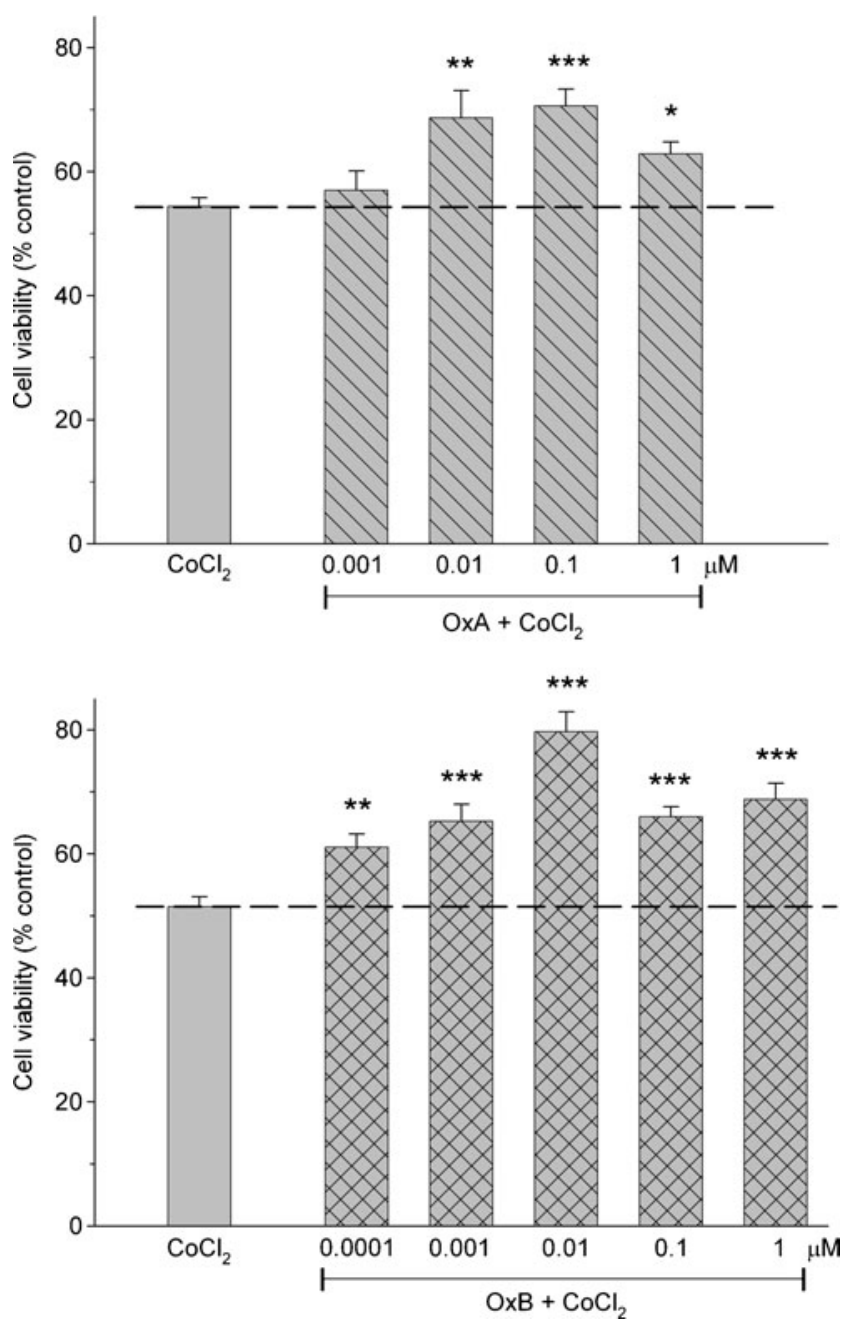

Fig. 3 Protective effects of orexins $\mathrm{A}$ and $\mathrm{B}$ in rat neuronal cultures challenged with cobalt chloride $(100 \mu \mathrm{M})$. Cells were incubated with the peptides $(0.0001-1 \mu \mathrm{M})$ in parallel with cobalt chloride for $48 \mathrm{~h}$ and cell viability was analyzed by MTT test. Data are mean \pm SEM of 6-24 values per group and expressed as a percentage of the respective control. Asterisks indicate statistically significant difference from cobalt chloride; ${ }^{*} P<$ $0.05 ; * * P<0.01 ; * * * P<0.001$

\section{Orexins Protect Cortical Neurons from the Cobalt} Chloride-Induced Oxidative Stress

Mitochondria act as $\mathrm{O}_{2}$ sensors by increasing the generation of ROS during hypoxia, and cobalt chloride mimics this response by inducing ROS generation (Chandel et al. 1998; Stenger et al. 2011). To confirm that orexins protect cortical neurons from the cobalt chloride toxicity, we measured oxidative stress level in rat cortical neurons using CM- $\mathrm{H}_{2}$ TMRos, a ROS-sensitive probe, in the presence or absence of cobalt chloride $(100 \mu \mathrm{M})$, treated with orexins at concentrations at which we observed the highest peptides responses, i.e., $0.1 \mu \mathrm{M}$ for orexin $\mathrm{A}$ and $0.01 \mu \mathrm{M}$ for orexin B. Both peptides diminished the cobalt chlorideinduced ROS generation to the basal level. In the absence of cobalt chloride, orexins did not alter cellular oxidative stress status (Fig. 4).

Akt Kinase Is Involved in Neuroprotection by Orexins Against the Cobalt Chloride Toxicity

To test whether activation of Akt kinase is involved in the neuroprotective effect of orexins, we measured neuronal viability in the presence of Akt kinase inhibitors, 10-DEBC hydrochloride $(2.5 \mu \mathrm{M})$ and GSK690693 $(1 \mu \mathrm{M})$. Control experiments performed in the absence of orexins revealed that these Akt inhibitors had no effect on the cobalt chloride toxicity in cortical neurons. When orexins were added together with Akt inhibitors to cortical neurons cultured under hypoxic conditions, the neuroprotective effect of peptides was completely abolished (Fig. 5). To test possible toxic effects of these inhibitors, neuronal cell cultures were treated with 10-DEBC hydrochloride and GSK690693, at concentrations used in experiments, and no toxicity was observed (data not shown).

\section{Discussion}

In the present work, we focused on the effect of orexins on Akt kinase stimulation in primary rat neuronal cultures and the significance of the orexin-induced Akt activation in neurons subjected to hypoxic stress. We have previously demonstrated that rat cortical neurons express both types of orexin receptors and their activation by orexins initiated different signaling pathways (Urbańska et al. 2012; Zawilska et al. 2013).

Despite of many literature reports indicating an ability of orexins to activate various intracellular signals, there are only a few findings demonstrating the effect of orexins on the Akt

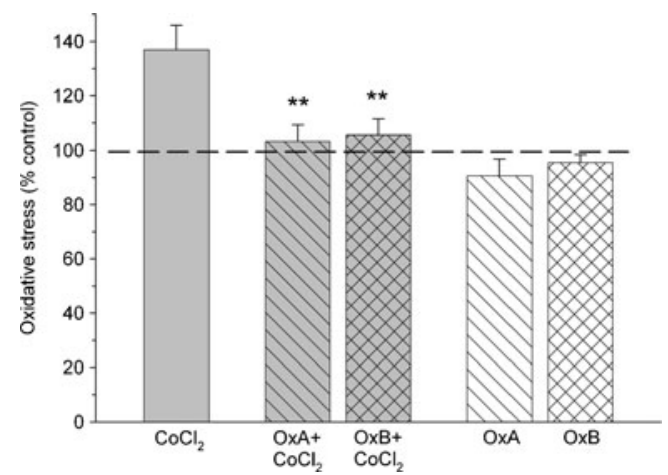

Fig. 4 Effects of orexins A and B on oxidative stress level in neuronal cultures from rat cerebral cortex. Neurons were treated with orexins A $(0.1 \mu \mathrm{M})$ and $\mathrm{B}(0.01 \mu \mathrm{M})$ for $24 \mathrm{~h}$ in the presence or absence of cobalt chloride $(100 \mu \mathrm{M})$ and stained with $\mathrm{CM}-\mathrm{H}_{2}$ TMRos. Data are mean \pm SEM of 5-12 replicates per group and expressed as a percentage of the respective control. Asterisks indicate statistically significant difference from control; **P<0.01 

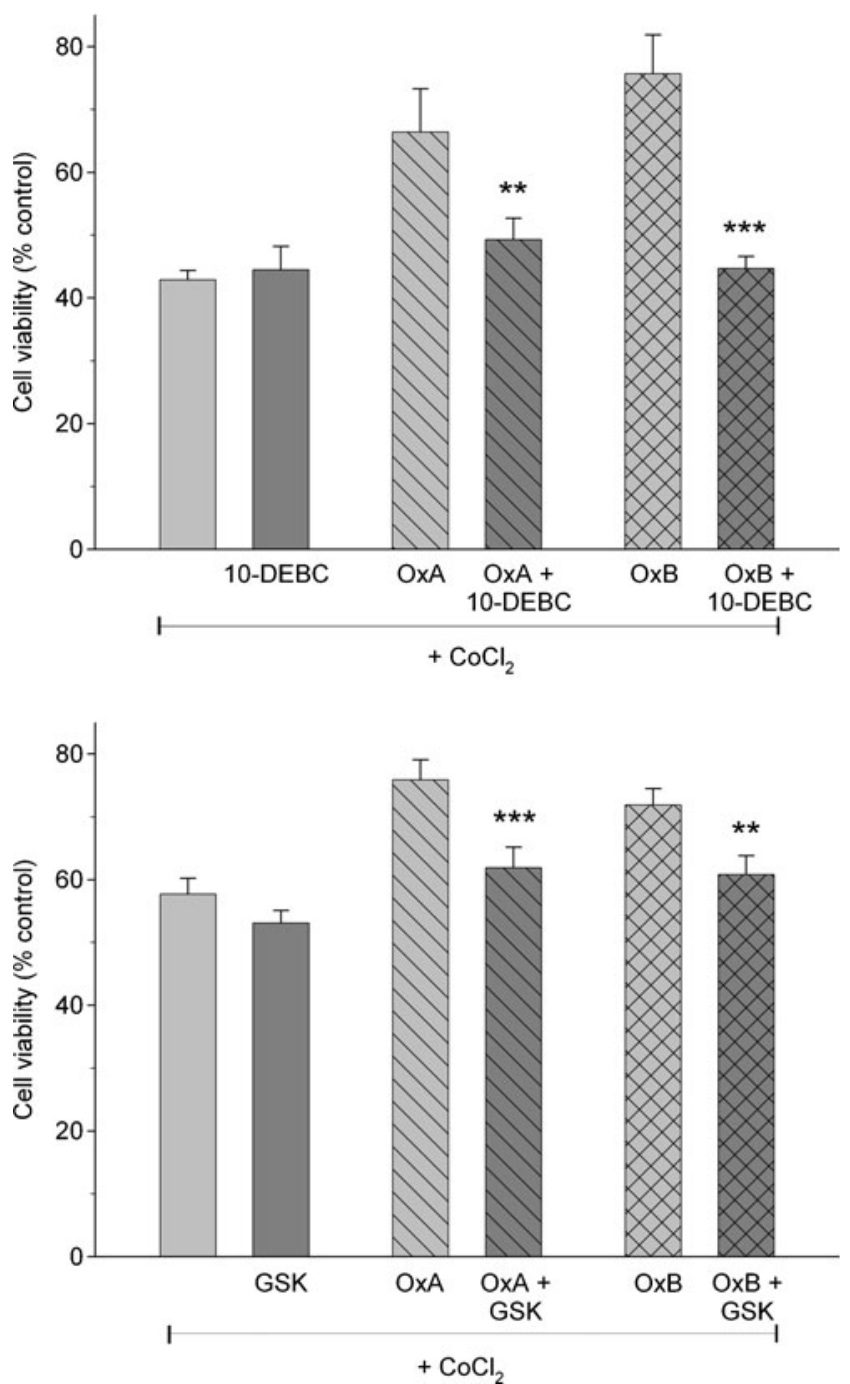

Fig. 5 Effects of Akt kinase inhibitors, 10-DEBC hydrochloride $(2.5 \mu \mathrm{M})$ and GSK690693 $(1 \mu \mathrm{M})$, on orexins A- $(0.1 \mu \mathrm{M})$ and Bstimulated $(0.01 \mu \mathrm{M})$ cell viability in rat neuronal cultures challenged with cobalt chloride $(100 \mu \mathrm{M})$. Data are mean \pm SEM of 6-19 values per group and expressed as a percentage of the respective control. Asterisks indicate statistically significant difference from orexins A and B, respectively; $* * P<0.01 ; * * * P<0.001$

signaling. For example, orexin A was shown to inhibit proglucagon gene expression through activation of Akt kinase in clonal pancreatic A cells (Göncz et al. 2007) and stimulated glucose uptake in primary rat adipocytes in a phosphatidylinositide 3-kinase-dependent manner (Skrzypski et al. 2011). The results obtained in the present study provide the first evidence that orexins A and B were able to potently induce Akt phosphorylation in rat primary cortical neurons. Both peptides acted at the wide range of concentrations and the calculated $\mathrm{EC}_{50}$ values were in low nanomolar range ( 2$7 \mathrm{nM}$ ), suggesting that the Akt stimulation is of physiological relevance. The orexins-mediated Akt response was rather slow as there was no statistically significant increase of Akt activity during the first $15 \mathrm{~min}$ of incubation. The most pronounced response was observed after one hour of incubation with the peptides. Interestingly, elevated phospho-Akt immunoreactivity was also observed after $24 \mathrm{~h}$, suggesting an involvement of Akt signaling in long-term cellular effects.

In different types of neuronal cells, the Akt signaling plays a crucial role in mediating survival signals (Brunet et al. 2001). This kinase also plays an important role in neurogenesis, axon establishment, and elongation (Diez et al. 2012). Altered Akt function has been associated to many pathologies, such as Alzheimer's disease (Liao and Xu 2009), Huntington disease (Warby et al. 2009; Zala et al. 2008), schizophrenia (Emamian et al. 2004), spinocerebellar ataxia type I (Chen et al. 2003), or autism (Kwon et al. 2006). Studies performed on recombinant cell lines have shown that orexins are capable of inducing both death- and survival-promoting signaling through activation of the classical MAPK pathways (Ammoun et al. 2006; Tang et al. 2008). The essential role of Akt signaling in neuronal survival and development prompted us to check whether this kinase mediates the orexin-initiated survival of cortical neurons against the cobalt-induced hypoxic toxicity. According to the literature, exposure to cobalt promotes a response similar to hypoxia by activating hypoxia-mediated signaling pathways aberrantly under normoxia and potently augmenting ROS generation in mitochondria (Chandel et al. 1998; Vengellur and LaPres 2004). Prolonged chemical hypoxia can also induce genes involved in cell death (Vengellur and LaPres 2004). In our study, we observed about $50 \%$ reduction of neuronal cells survival after 48-h incubation with cobalt chloride at $100 \mu \mathrm{M}$. Orexins, added to hypoxic neuronal cultures, potently attenuated cobalt toxicity. In this context, it is worth to note that our previous findings in cortical neurons cultures showed the stimulatory effect of orexins $A$ and $B$ on neuronal survival under normoxia with a parallel attenuation of caspase- 3 activity, indicating a new role of orexins as potential neuroprotective factors (Sokołowska et al. 2012). Recently, Butterick et al. (2012) have demonstrated that orexins protected immortalized hypothalamic neurons against $\mathrm{H}_{2} \mathrm{O}_{2}$-induced toxicity by decreasing lipid peroxidative stress and caspase-dependent apoptosis. In the light of these findings orexins seem to be neuroprotective against oxidative stress by modulation of anti-apoptotic mechanisms. Although the knowledge of the orexin-evoked neuroprotection is evolving, there are still many questions concerning factors mediating neuronal survival. Results from the present study point at an important role of Akt as one of the possible mediators of the pro-survival effects of orexins in neurons. Two Akt inhibitors, 10-DEBC hydrochloride and GSK690693, entirely suppressed the orexins A- and B-induced protection of cortical neurons from cobalt toxicity. Thus, the role of Akt in this process seems to be undeniable.

The question remains how the orexin-activated Akt induces the anti-apoptotic machinery. A series of studies with 
the use of survival factors have demonstrated that Akt directly phosphorylates a major class of transcription factors - the Forkhead box transcription factor, class $\mathrm{O}$ and inhibits their ability to induce the expression of death genes (Brunet et al. 1999). Akt was also reported to promote cell survival by inhibiting the activity of p53 or inducing the expression of survival genes by activating two transcription factors, cAMPresponsive element binding protein, and nuclear factor $\mathrm{KB}(\mathrm{Du}$ and Montminy 1998; Ozes et al. 1999; Yamaguchi et al. 2001). In addition to its effects on transcription, Akt phosphorylates $\mathrm{BAD}$ (Bcl-2 family member) inhibiting BAD proapoptotic functions (Datta et al. 1997). It is also suggested that Akt may promote survival indirectly by affecting cellular metabolism. In particular, Akt prevents the depletion of metabolites by increasing ATP or glucose levels (Brunet et al. 2001). Thus, it seems possible that orexins, the well-known factors influencing metabolism, arousal, and energy expenditure, may regulate energy balance towards cell survival with the Akt contribution to this process. Understanding the molecular mechanisms of orexin-promoted neuroprotection could be addressed in future studies to design new therapies of brain pathologies.

In summary, we demonstrated the first evidence that both orexins A and B potently stimulated Akt activation in primary neuronal cultures from rat cerebral cortex. We also showed that orexins protected cortical neurons against cobalt-induced oxidative stress and pointed at the important role of Akt as the mediator of pro-survival effects of orexins in neurons.

Acknowledgment This work was supported by a grant from the Ministry of Science and Higher Education, Warsaw, Poland (no. 4254/B/PO1/ 2010/38).

Conflict of Interest The authors state no conflict of interest.

Open Access This article is distributed under the terms of the Creative Commons Attribution License which permits any use, distribution, and reproduction in any medium, provided the original author(s) and the source are credited.

\section{References}

Alvarez CE, Sutcliffe JG (2002) Hypocretin is an early member of the incretin gene family. Neurosci Lett 324:169-172

Ammoun S, Holmqvist T, Shariatmadari R, Oonk HB, Detheux M, Parmentier M, Åkerman KE, Kukkonen JP (2003) Distinct recognition of $\mathrm{OX}_{1}$ and $\mathrm{OX}_{2}$ receptors by orexin peptides. J Pharmacol Exp Ther 305:507-514

Ammoun S, Lindholm D, Wootz H, Åkerman KEO, Kukkonen JP (2006) G-protein-coupled $\mathrm{OX}_{1}$ orexin/hcrtr-1 hypocretin receptors induce caspase-dependent and -independent cell death through p38 mitogen-/stress-activated protein kinase. J Biol Chem 281:834-842

Aston-Jones G, Smith RJ, Sartor GC, Moorman DE, Massi L, TahsiliFahadan P, Richardson KA (2010) Lateral hypothalamic orexin/ hypocretin neurons: a role in reward seeking and addiction. Brain Res 1314:74-90
Berthoud HR, Patterson LM, Sutton GM, Morrison C, Zheng H (2005) Orexin inputs to caudal raphe neurons involved in thermal, cardiovascular, and gastrointestinal regulation. Histochem Cell Biol 123:147-156

Brewer GJ (1995) Serum-free B27/neurobasal medium supports differentiated growth of neurons from the striatum, substantia nigra, septum, cerebral cortex, cerebellum, and dentate gyrus. J Neurosci Res 42:674-483

Brunet A, Bonni A, Zigmond MJ, Lin MZ, Juo P, Hu LS, Anderson MJ, Arden KC, Blenis J, Greenberg ME (1999) Akt promotes cell survival by phosphorylating and inhibiting a Forkhead transcription factor. Cell 96:857-868

Brunet A, Datta SR, Greenberg ME (2001) Transcription-dependent and independent control of neuronal survival by the PI3K-Akt signaling pathway. Curr Opin Neurobiol 11:297-305

Butterick TA, Nixon JP, Billington CJ, Kotz CM (2012) Orexin A decreases lipid peroxidation and apoptosis in a novel hypothalamic cell model. Neurosci Lett 524:30-34

Chandel NS, Maltepe E, Goldwasser E, Mathieu CE, Simon MC, Schumacker PT (1998) Mitochondrial reactive oxygen species trigger hypoxia-induced transcription. Proc Natl Acad Sci U S A 95: $11715-11720$

Chemelli RM, Willie JT, Sinton CM, Elmquist JK, Scammell T, Lee C, Richardson JA, Williams SC, Xiong Y, Kisanuki Y, Fitch TE, Nakazato M, Hammer RE, Saper CB, Yanagisawa M (1999) Narcolepsy in orexin knockout mice: molecular genetics of sleep regulation. Cell 98:437-451

Chen HK, Fernandez-Funez P, Acevedo SF, Lam YC, Kaytor MD, Fernandez MH, Aitken A, Skoulakis EM, Orr HT, Botas J, Zoghbi HY (2003) Interaction of Akt-phosphorylated ataxin-1 with 14-3-3 mediates neurodegeneration in spinocerebellar ataxia type 1 . Cell 113:457-468

Datta SR, Dudek H, Tao X, Masters S, Fu H, Gotoh Y, Greenberg ME (1997) Akt phosphorylation of BAD couples survival signals to the cell-intrinsic machinery. Cell 91:231-241

de Lecea L, Kilduff TS, Peyron C, Gao XB, Foye PE, Danielson PE, Fukuhara C, Battenberg ELF, Gautvik VT, Bartlett VS, Frankel WN, van den Pol N, Bloom E, Gautvik KM, Sutcliffe JG (1998) The hypocretins: hypothalamus-specific peptides with neuroexcitatory activity. Proc Natl Acad Sci U S A 95:322-327

Diez H, Garrido JJ, Wandosell F (2012) Specific roles of Akt isoforms in apoptosis and axon growth regulation in neurons. PLoS One 7:e32715

Du K, Montminy M (1998) CREB is a regulatory target for the protein kinase Akt/PKB. J Biol Chem 273:32377-32379

Emamian ES, Hall D, Birnbaum MJ, Karayiorgou M, Gogos JA (2004) Convergent evidence for impaired AKT-GSK $3 \beta$ signaling in schizophrenia. Nat Genet 36:131-137

Göncz E, Strowski MZ, Grotzinger C, Nowak KW, Kaczmarek P, Sassek M, Mergler S, El-Zayat BE, Theodoropoulou M, Stalla GK, Wiedenmann B, Plöckinger U (2007) Orexin-A inhibits glucagon secretion and gene expression through a Foxo1-dependent pathway. Endocrinology 149:1618-1626

Holmqvist T, Johansson L, Ostman M, Ammoun S, Åkerman KEO, Kukkonen JP (2005) $\mathrm{OX}_{1}$ orexin receptors couple to adenylyl cyclase regulation via multiple mechanisms. J Biol Chem 280:6570-6579

Ibarretxe G, Sanchez-Gomez MV, Campos-Esparza MR, Alberdi E, Matute C (2006) Differential oxidative stress in oligodendrocytes and neurons after excitotoxic insults and protection by natural polyphenols. Glia 53:201-211

Johansson L, Ekholm ME, Kukkonen JP (2007) Regulation of $\mathrm{OX}_{1}$ orexin/hypocretin receptor-coupling to phospholipase $\mathrm{C}$ by $\mathrm{Ca}^{2+}$ influx. Br J Pharmacol 150:97-104

Kitamura E, Hamada J, Kanazawa N, Yonekura J, Masuda R, Sakai F, Mochizuki H (2010) The effect of orexin-A on the pathological mechanism in the rat focal cerebral ischemia. Neurosci Res 68:154-157

Kukkonen JP (2012) Physiology of the orexinergic/hypocretinergic system: a revisit in 2012. Am J Physiol Cell Physiol 304:C2-C32 
Kukkonen JP, Holmqvist T, Ammoun S, Åkerman KEO (2002) Functions of the orexinergic/hypocretinergic system. Am J Physiol Cell Physiol 283:1567-1591

Kweon SM, Kim HJ, Lee ZW, Kim SJ, Kim SI, Paik SG, Ha KS (2001) Real-time measurement of intracellular reactive oxygen species using Mito tracker orange ( $\left.\mathrm{CMH}_{2} \mathrm{TMRos}\right)$. Biosci Rep 21:341-352

Kwon CH, Luikart BW, Powell CM, Zhou J, Matheny SA, Zhang W, Li Y, Baker SJ, Parada LF (2006) Pten regulates neuronal arborization and social interaction in mice. Neuron 50:377-388

Lampe K, Bjugstad KB, Mahoney MJ (2010) Impact of degradable macromer content in a poly(ethylene glycol) hydrogel on neural cell metabolic activity, redox state, proliferation, and differentiation. Tissue Eng A 16:1857-1866

Liao FF, Xu H (2009) Insulin signaling in sporadic Alzheimer's disease. Sci Signal 2:pe36

Lund PE, Shariatmadari R, Uustare A, Detheux M, Parmentier M, Kukkonen JP, Akerman KEO (2000) The orexin $\mathrm{OX}_{1}$ receptor activates a novel $\mathrm{Ca}^{2+}$ influx pathway necessary for coupling to phospholipase C. J Biol Chem 275:30806-30812

Magga J, Bart G, Oker-Blom C, Kukkonen JP, Åkerman KE, Nasman J (2006) Agonist potency differentiates $\mathrm{G}$ protein activation and $\mathrm{Ca}^{2+}$ signalling by the orexin receptor type 1 . Biochem Pharmacol 71 : $827-836$

Mazzocchi G, Malendowicz LK, Aragona F, Rebuffat P, Gottardo L, Nussdorfer GG (2001) Human pheochromocytomas express orexin receptor type 2 gene and display an in vitro secretory response to orexins A and B. J Clin Endocrinol Metab 86:4818-4821

Mieda M, Willie JT, Hara J, Sinton CM, Sakurai T, Yanagisawa M (2004) Orexin peptides prevent cataplexy and improve wakefulness in a orexin-ablated model of narcolepsy in mice. Proc Natl Acad Sci U S A 101:4649-4654

Nambu T, Sakurai T, Mizukami K, Hosoya Y, Yanagisawa M, Goto K (1999) Distribution of orexin neurons in the adult rat brain. Brain Res 827:243-260

Nowak JZ, Jozwiak-Bebenista M, Bednarek K (2007) Effects of PACAP and VIP on cyclic AMP formation in rat neuronal and astrocyte cultures under normoxic and hypoxic condition. Peptides 28:1706-1712

Ozes ON, Mayo LD, Gustin JA, Pfeffer SR, Pfeffer LM, Donner DB (1999) NF- $k B$ activation by tumour necrosis factor requires the Akt serine-threonine kinase. Nature 401:82-85

Peyron C, Tighe DK, van den Pol AN, de Lecea L, Heller HC, Sutcliffe JG, Kilduff TS (1998) Neurons containing hypocretin (orexin) project to multiple neuronal systems. J Neurosci 18:9996-10015

Ramanjaneya M, Conner AC, Chen J, Kumar P, Brown JEP, Jöhren O, Lehnert H, Stanfield PR, Randeva HS (2009) Orexin-stimulated MAP kinase cascades are activated through multiple G-protein signaling pathways in human H295R adrenocortical cells: diverse roles for orexins A and B. J Endocrinol 202:249-261

Randeva HS, Karteris E, Grammatopoulos D, Hillhouse EW (2001) Expression of orexin-A and functional orexin type 2 receptors in the human adult adrenals: implications for adrenal function and energy homeostasis. J Clin Endocrinol Metab 86:4808-4813

Rouet-Benzineb P, Rouyer-Fessard C, Jarry A, Avondo V, Pouzet C, Yanagisawa M, Laboisse C, Laburthe M, Voisin T (2004) Orexins acting at native $\mathrm{OX}_{1}$ receptor in colon cancer and neuroblastoma cells or at recombinant $\mathrm{OX}_{1}$ receptor suppress cell growth by inducing apoptosis. J Biol Chem 279:45875-45886

Sakurai T, Amemiya A, Ishii M, Matsuzaki I, Chemelli RM, Tanaka H, Williams SC, Richardson JA, Kozlowski GP, Wilson S, Arch JR, Buckingham RE, Haynes AC, Carr SA, Annan RS, McNulty DE, Liu WS, Terrett JA, Elshourbagy NA, Bergsma DJ, Yanagisawa M (1998) Orexins and orexin receptors: a family of hypothalamic neuropeptides and $\mathrm{G}$ protein-coupled receptors that regulate feeding behavior. Cell 92:573-585

Skrzypski M, Le TT, Kaczmarek P, Pruszynska-Oszmalek E, Pietrzak P, Szczepankiewicz D, Kolodziejski PA, Sassek M, Arafat A, Wiedenmann B, Nowak KW, Strowski MZ (2011) Orexin A stimulates glucose uptake, lipid accumulation and adiponect in primary rat adipocytes. Diabetologia 54:1841-1852

Sokołowska P, Urbańska A, Namiecińska M, Biegańska K, Zawilska JB (2012) Orexins promote survival of rat cortical neurons. Neurosci Lett 506:303-306

Spinazzi R, Andreis PG, Rossi GP, Nussdorfer GG (2006) Orexins in the regulation of the hypothalamic-pituitary-adrenal axis. Pharmacol Rev 58:46-57

Stenger C, Naves T, Verdier M, Ratinaud MH (2011) The cell death response to the ROS inducer, cobalt chloride, in neuroblastoma cell lines according to p53 status. Int J Oncol 39:601-609

Tang J, Chen J, Ramanjaneya M, Punn A, Conner AC, Randeva HS (2008) The signalling profile of recombinant human orexin-2 receptor. Cell Signal 20:1651-1661

Thompson JL, Borgland SL (2011) A role for hypocretin/orexin in motivation. Behav Brain Res 217:446-453

Urbańska A, Sokołowska P, Woldan-Tambor A, Biegańska K, Brix B, Jöhren O, Namiecińska M, Zawilska JB (2012) Orexins/hypocretins acting at $\mathrm{G}_{\mathrm{i}}$ protein-coupled $\mathrm{OX}_{2}$ receptors inhibit cyclic AMP synthesis in the primary neuronal cultures. J Mol Neurosci 46:10-17

Vengellur A, LaPres JJ (2004) The role of hypoxia inducible factor $1 \alpha$ in cobalt chloride induced cell death in mouse embryonic fibroblasts. Toxicol Sci 82:638-646

Voisin T, Rouet-Benzineb P, Reuter N, Laburthe M (2003) Orexins and their receptors: structural aspects and role in peripheral tissue. Cell Mol Life Sci 60:72-87

Warby SC, Doty CN, Graham RK, Shively J, Singaraja RR, Hayden MR (2009) Phosphorylation of huntingtin reduces the accumulation of its nuclear fragments. Mol Cell Neurosci 40:121-127

Woldan-Tambor A, Biegańska K, Wiktorowska-Owczarek A, Zawilska JB (2011) Activation of orexin/hypocretin type 1-like receptors stimulates cAMP synthesis in primary cultures of rat astrocytes. Pharmacol Rep 63:717-723

Yamaguchi A, Tamatani M, Matsuzaki H, Namikawa K, Kiyama H, Vitek MP, Mitsuda N, Tohyama M (2001) Akt activation protects hippocampal neurons from apoptosis by inhibiting transcriptional activity of p53. J Biol Chem 276:5256-5264

Yuan LB, Dong HL, Zhang HP, Zhoa RN, Gong G, Chen XM, Zhang LN, Xiong L (2011) Neuroprotective effect of orexin-A is mediated by an increase of hypoxia-inducible factor- 1 activity in rat. Anesthesiology 114:340-354

Zala D, Colin E, Rangone H, Liot G, Humbert S, Saudou F (2008) Phosphorylation of mutant huntingtin at S421 restores anterograde and retrograde transport in neurons. Hum Mol Genet 17: $3837-3846$

Zawilska JB, Urbańska A, Sokołowska P (2013) Orexins/hypocretins stimulate accumulation of inositol phosphate in primary cultures of rat cortical neurons. Pharmacol Rep 65:513-516

Zhang W, Zhang N, Sakurai T, Kuwaki T (2009) Orexin neurons in the hypothalamus mediate cardiorespiratory responses induced by disinhibition of the amygdale and bed nucleus of the stria terminalis. Brain Res 1262:25-37

Zhu Y, Miwa Y, Yamanaka A, Yada T, Shibahara M, Abe Y, Sakurai T, Goto K (2003) Orexin receptor type-1 couples exclusively to pertussis toxin-insensitive G-proteins, while orexin receptor type-2 couples to both pertussis toxin-sensitive and -insensitive Gproteins. J Pharmacol Sci 92:259-266 